\title{
QUATERNARY SEDIMENTATION, NEOTECTONICS AND THE EVOLUTION OF THE DOCE RIVER MIDDLE VALLEY LAKE SYSTEM (SOUTHEASTERN BRAZIL)
}

\author{
Claudio Limeira MELLO \\ Cynthia Maria Soares METELO \\ Kenitiro SUGUIO \\ Heinz Charles KOHLER.
}

\section{RESUMO}

A região do Médio Vale do Rio Doce, situada no Estado de Minas Gerais, no Sudeste do Brasil, constitui uma das áreas mais importantes para o estudo da evolução quaternária dos trópicos úmidos em território brasileiro. Esta área apresenta um sistema singular de lagos barrados, anteriormente investigados por diversos autores, particularmente na década de 70 . A maioria dos estudos anteriores referiu-se a condicionantes paleoclimáticos como responsáveis pela origem e evolução do sistema de lagos. Alguns autores reconheceram, ainda, evidências da atuação de mecanismos neotectônicos na sua formação e desenvolvimento. O presente estudo discute uma nova abordagem acerca da evolução quaternária desta área, na qual a origem e a evolução do sistema de lagos são interpretadas com base em investigações estratigráficas e estruturais regionais. Dados geofísicos (sismoestratigráficos) fornecem novas evidências a respeito da estratigrafia dos sedimentos lacustres. Análises estruturais detalhadas de juntas e falhas afetando os sedimentos quaternários sustentam interpretações neotectônicas. As análises estratigráficas realizadas confirmam o início da sedimentação lacustre por volta de 9.000 anos AP, simultaneamente a uma importante sedimentação aluvial regional. Análises sismoestratigráficas realizadas na desembocadura do Lago Dom Helvécio documentam uma falha normal afetando sedimentos aluviais holocênicos, podendo explicar a barragem deste lago e sugerindo mecanismos neotectônicos como o principal controle para a origem do sistema de lagos do Médio Vale do Rio Doce.

Palavras-chave: Quaternário, geomorfologia, neotectônica, sistemas de lagos barrados, Vale do Rio Doce, Brasil de Sudeste.

\section{ABSTRACT}

The Doce River Middle Valley (State of Minas Gerais, Southeastern Brazil) is one of the most important areas in Brazil in the study of Quaternary evolution of the humid tropics. This area preserves a singular barred-lake system which has been previously investigated by several authors, particularly on the 70's. Most previous studies have considered paleoclimatic controls as responsible for the origin and the evolution of the lake system. Some authors have also recognized evidences of neotectonic influence on the lacustrine development. In the present study, a new approach to the Quaternary evolution of this area is discussed. The origin and the evolution of the lake system are interpreted according to regional stratigraphic and structural investigations. Geophysical (seismic stratigraphic) data provide new insights about the lake stratigraphy. Detailed structural analyses of joints and faults affecting Quaternary sediments support neotectonic interpretations. Stratigraphic analyses confirm the beginning of the lacustrine sedimentation around 9,000 years BP, simultaneously with an important regional alluvial sedimentation. Seismic stratigraphic analysis performed at the dam of Dom Helvécio Lake shows a normal fault affecting Holocene alluvial sediments. It explains the damming of this lake and suggests neotectonic mechanisms as the main control for the origin of the Doce River Middle Valley lake system.

Keywords: Quaternary, geomorphology, neotectonics, barred lake system, Doce River Valley, Southeastern Brazil. 


\section{INTRODUCTION}

Remarkable geomorphologic and sedimentologic features observed in the Doce River Middle Valley (State of Minas Gerais, Southeastern Brazil) have been considered as potentially important to explain the Quaternary paleoenvironmental evolution of humid tropics in Brazil, especially with regard to paleoclimatic and neotectonic controls. The area is situated in a huge depressed topographic compartment (Figure 1), related by several authors to Cenozoic tectonic mechanisms. Significant sedimentary deposits associated with welldeveloped recent geomorphic features are preserved. The most impressive feature in the region is a Quaternary barred-lake system (Figure 2). Since the area was not affected by Quaternary sea-level variations, the regional landscape evolution reflects fluvial network responses to paleohydrologic and/or base-level changes.

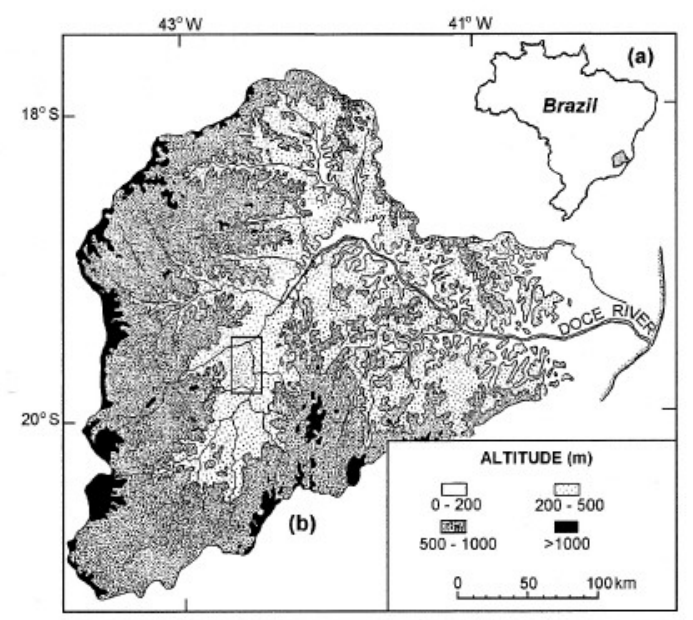

FIGURE 1 - (a) Location map of the Doce River basin (State of Minas Gerais, Southeastern Brazil). (b) Hypsometric map of the Doce River basin assigning the location of the lake system in the "Interplateau Lowlands of the Doce River Middle Valley" (after MEIS \& MACHADO 1978).

PFLUG (1969) was the first author to perform geomorphologic studies in the area. He proposed that the lake system was caused by the damming of small tributary valleys of the Doce River due to intense alluvial accumulation. According to him, this evolution occurred under semi-arid climatic conditions, during a time interval contemporaneous with the Last Ice Age of the Northern Hemisphere. Modern semihumid tropical conditions were responsible for

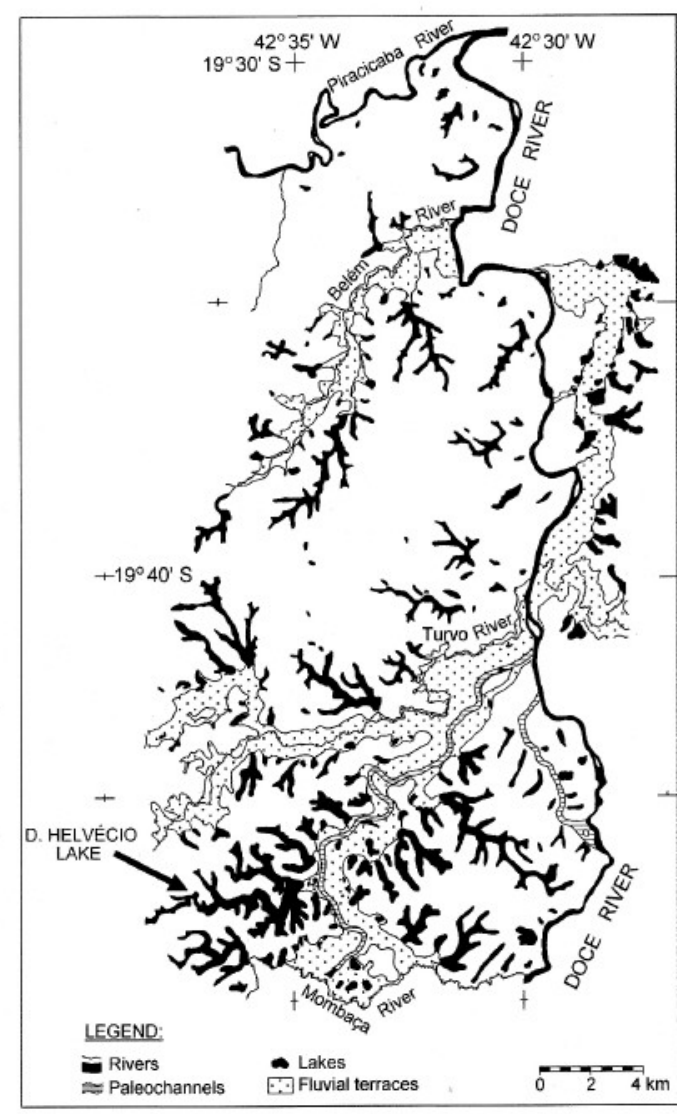

FIGURE 2 - Map of alluvial forms and lacustrine bodies in the area of main concentration of lakes in the Doce River Middle Valley - Doce River Forest Park (after BARBOSA \& KOHLER 1981). Note the string of lacustrine bodies associated with paleochannels and infilled valleys. In the present work, the Dom Helvécio Lake was studied in detail.

the posterior drowning of the dammed valleys.

Meis and collaborators studied the Doce River Middle Valley lake system with a morphostratigraphic approach (MEIS 1977, MEIS \& MACHADO 1978, MEIS \& MONTEIRO 1979), identifying sets of slope deposits ("rampas" complexes) and fluvial and lacustrine deposits. Confirming PFLUG (1969), these authors recognized that a rapid fluvial aggradation of the main valleys at the end of the Pleistocene resulted in the damming of the smaller creeks and originated the lakes. MEIS \& MONTEIRO (1979) considered two phases of lacustrine submersion. The first one was dated at the Pleistocene/Holocene boundary and the second one was dated at $7,830 \pm 250$ years BP to $3,365 \pm 115$ years BP. In their studies, Meis 
and collaborators assumed paleoclimatic changes as the main morphogenic control.

Palynologic studies have led to other paleoclimatic considerations (OVERLOOP 1981, BEHLING 1995, YBERT et al. 1997). According to these studies, Holocene humid conditions and a first lake submersion are only recognizable after 9,000 years $\mathrm{BP}$, which suggests a more recent age for the lake system.

BARBOSA \& KOHLER (1981), SAADI (1991) and SUGUIO \& KOHLER (1992) presented evidences of neotectonic processes on the lake system formation. They discussed geomorphologic aspects, such as lake alignments, lake margin straightness, infilled paleovalleys and lake strings associated with abrupt fluvial migrations, as important indicators of neotectonic controls on the lake system evolution.

The present paper aims to discuss the Quaternary evolution of the Doce River Middle Valley lake system based on a new approach that integrates regional stratigraphic and structural analyses. The lacustrine depressions are specifically investigated in terms of stratigraphy and possible deformational structures.

\section{REGIONAL SETTING}

The study area is inserted in the occidental portion of the Mantiqueira Structural Province, as defined by ALMEIDA et al. (1977), comprising a complex set of Precambrian gneisses, migmatites, granites and granodiorites. Remnants of greenstone belts are also present. The lithologic units are distributed along NNE-SSW belts. Most of the area is constituted by banded biotite-rich gneisses, which are locally migmatitic (Mantiqueira Complex - DNPM 1978).

The area is geomorphologically part of the "Interplateau Lowlands of the Doce River Middle Valley" (IGA-MG 1977) - Figure 1, that correspond to an important physiographic feature of Southeastern Brazil. It represents a $200 \mathrm{~km}$ long and $50 \mathrm{~km}$ wide depressed area, striking on a NNE-SSW direction. This feature is strongly controlled by Precambrian structures and its evolution is related to Cenozoic brittle tectonics.

Inside this depressed area, the morphology is characterized by hilly lowlands with altitudes between $200 \mathrm{~m}$ and $500 \mathrm{~m}$. There is a remarkable zone, approximately $20 \mathrm{~km}$ wide and $80 \mathrm{~km}$ long, accompanying the Doce River course, that is marked by infilled valleys and barred lakes.

The lakes have irregular dimensions, up to more than $5 \mathrm{~km}$ long and more than $4 \mathrm{~km}^{2}$ in area (MEIS \& TUNDISI 1986). Their digitate or dendritic shapes confirm their origin associated with the drowning of ancient tributary valleys.

The regional climate is classified as tropical, warm and semi-humid (NIMER 1989). The annual mean temperature varies between $20^{\circ} \mathrm{C}$ and $22^{\circ} \mathrm{C}$, and the annual mean rainfall varies from $1,250 \mathrm{~mm}$ to $1,500 \mathrm{~mm}$. Rainfall is concentrated in the summer.

A tropical Atlantic forest and a vegetation transitional between forest and cerrado were present until the beginning of $20^{\text {th }}$ century. The native vegetation has been almost destroyed and has been replaced by pasture and eucalyptus plantations. It is locally preserved in the Doce River Forest Park (IEF-MG). There are swampy areas with corresponding vegetation.

\section{METHODS}

In this work, regional stratigraphic and structural analyses were carried out. A special attention was given to the area where the lakes are preserved.

The stratigraphic analyses included morphostratigraphic and allostratigraphic perspectives, emphasizing the reconnaissance of depositional surfaces and discontinuities in the stratigraphic record. The main areas of sedimentary accumulation were mapped using aerial photos since they are characterized by well-developed Quaternary features, such as fluvial terraces and "rampas" complexes. The most representative morphologic features were investigated by stratigraphic reconstruction of natural exposures (roadcuts and alluvial cliffs).

A high-resolution seismic analysis accompanied by drilling was performed in order to study the stratigraphy of the lacustrine bodies. The Dom Helvécio Lake, the largest one in the Doce River Middle Valley lake system, was selected for this analysis (Figure 2).

The stratigraphic studies were complemented by radiocarbon datings that were carried out by Beta Analytic Inc. (USA).

Joints and faults affecting the sediments were carefully measured. A rigorous stratigraphic 
control and the analysis of kinematic indicators support a discussion of their chronology. Fault planes with slickensides were analyzed by the ANGELIER \& MECHLER (1977) method.

\section{ALLUVIAL SEDIMENTATION AND NEOTECTONICS}

As discussed by some previous authors (PFLUG 1969, MEIS 1977, BARBOSA \& KOHLER 1981), the Doce River Middle Valley lake system is characterized by a significant relationship between the lacustrine bodies and geomorphic features such as infilled valleys and paleochannels.

The map of alluvial forms and lacustrine bodies presented by BARBOSA \& KOHLER (1981) for the area of the Doce River Forest Park (Figure 2) documents a well-developed fluvial terrace surface bordered by lacustrine bodies in the Doce, Mombaça, Turvo and Belém river valleys. The highest concentration of lakes is found along a paleochannel trace.

In order to discuss the relation between the Quaternary alluvial sedimentation and the lacustrine evolution, a regional stratigraphic analysis was performed. Several stratigraphic sections were studied and a seismic profile and a drill hole at the mouth of an important lacustrine depression (Dom Helvécio Lake) were also performed.

The regional stratigraphic analysis resulted in identification of four major depositional events during the Cenozoic sedimentary evolution of the Doce River Middle Valley (Figure 3). One of these events corresponds to an intensive and widespread alluvial-colluvial sedimentation, responsible for the filling-up of headwaters and valleys (Santo Antônio do Requerente Alloformation), and dated at the early to middle Holocene. The alluvial surface associated with the lacustrine bodies was produced by this Holocene sedimentation.
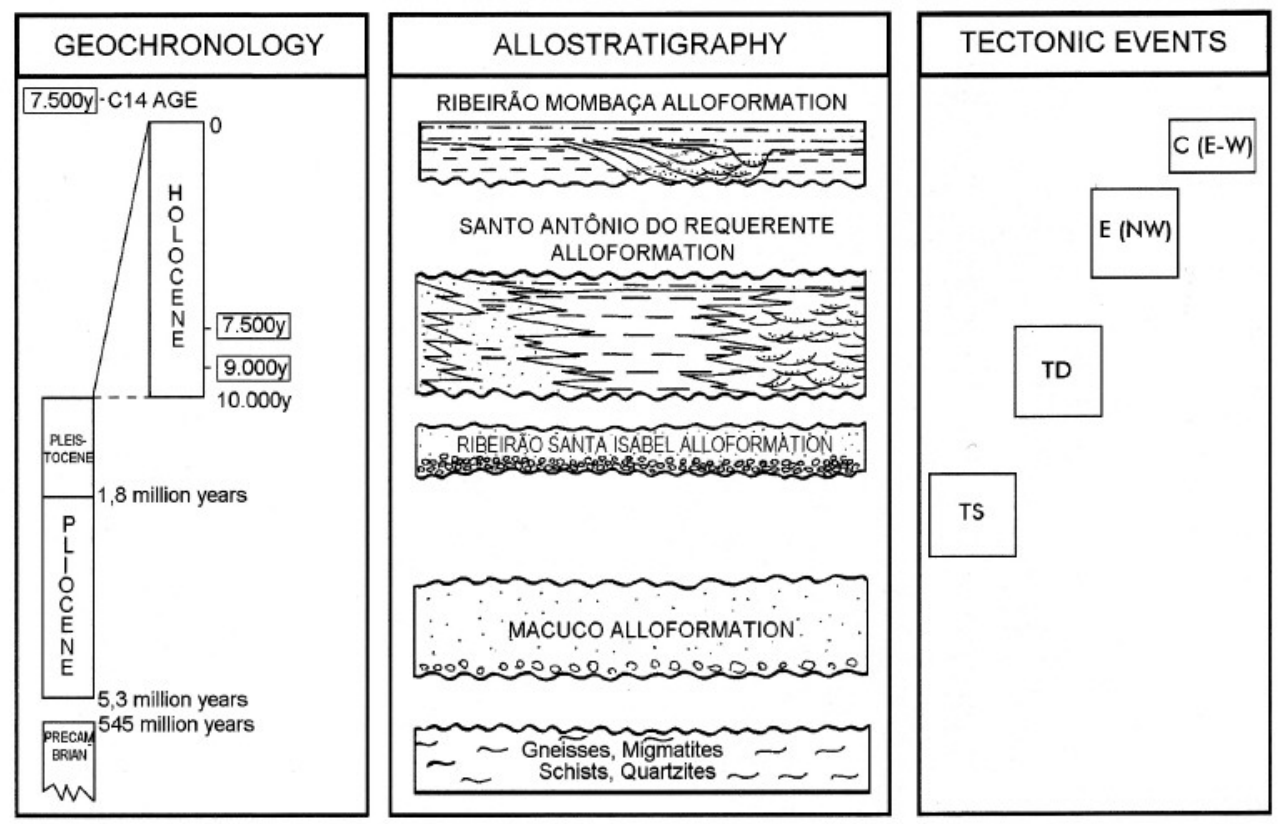

FIGURE 3 - Cenozoic allostratigraphic units and tectonic events in the Doce River Middle Valley (after MELLO 1997).

Two stratigraphic sections are here described aiming to represent the main stratigraphic, sedimentologic and structural relationships regarding to the evolution of the infilled valleys and lakes (figures 4 and 5).

The Fazenda Conquista (A) Section (Figure 4) reproduces the main stratigraphic aspects of the infilled valleys. The sedimentary succession is marked by the interbedding of tabular layers of very oxidized, horizontally stratified sandy deposits (flashflood deposits) and massive clayey deposits (mudflow deposits). Near the bottom of this section, an organic-rich clayey layer was dated at 9,020 $\pm 230{ }^{14} \mathrm{C}$ years $\mathrm{BP}$ (charcoal, Beta-97071). This stratigraphic level seems to be very close to the beginning of the 
alluvial sedimentation associated with the widespread filling of the valleys. The sedimentologic characteristics indicate that an alluvial fan and low-sinuosity river system was active during the early to middle Holocene times.

The alluvial fan morphology can be still

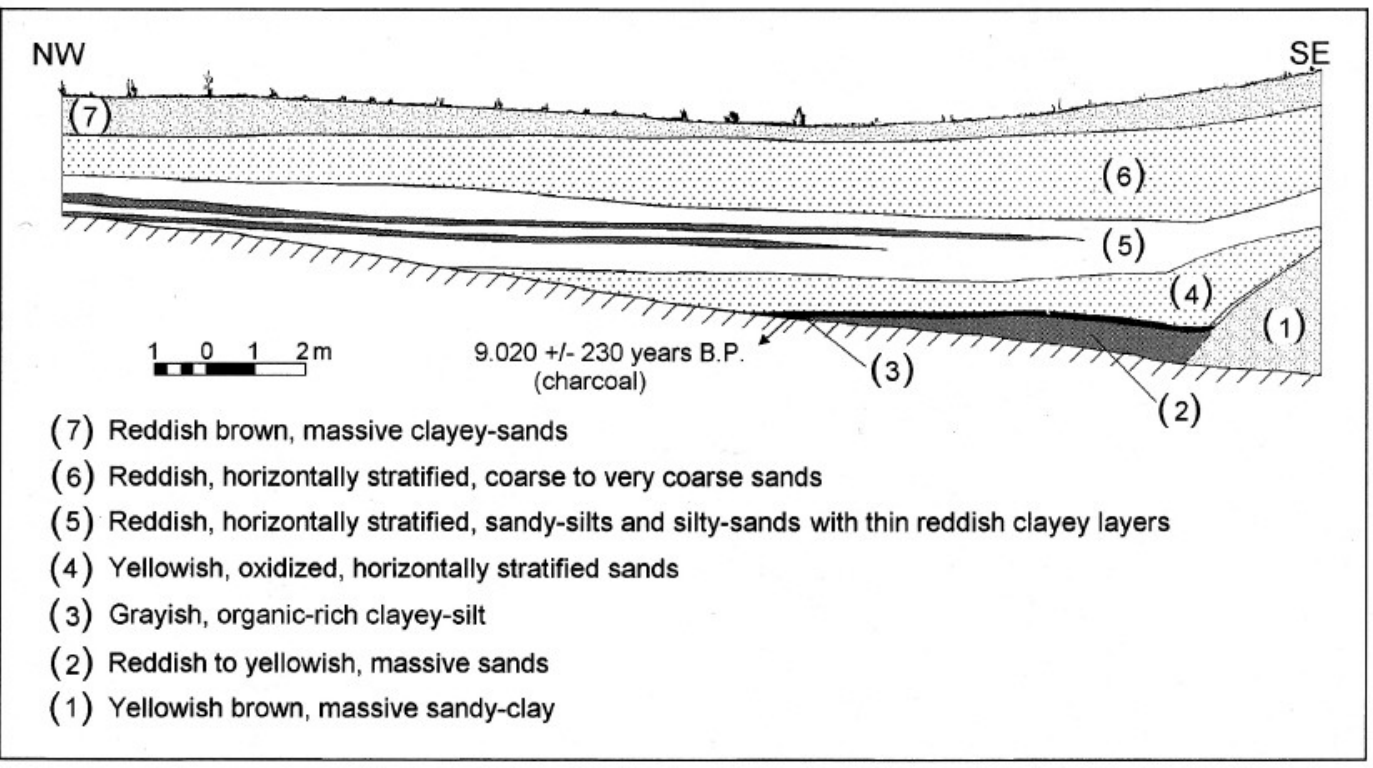

FIGURE 4 - Fazenda Conquista (A) Section reproduces the stratigraphic reconstruction of a typical infilled valley of the study-area. The alluvial sedimentation is dated at early to middle Holocene.

mapped on the present landscape, dissecting NW-SE oriented interfluves. It was verified that these interfluves configure horsts.

The Córrego Grande (B) Section (Figure 5) exhibits the stratigraphic and structural framework of one of those NW-SE interfluves.
At this section, an organic-rich horizon dated at $9,990 \pm 80{ }^{14} \mathrm{C}$ years BP (charcoal, Beta-97068) is displaced by a NW-SE transtensional fault. This fault can be related to an E-W dextral transcurrence that was regionally identified in the study-area (Figure 3).

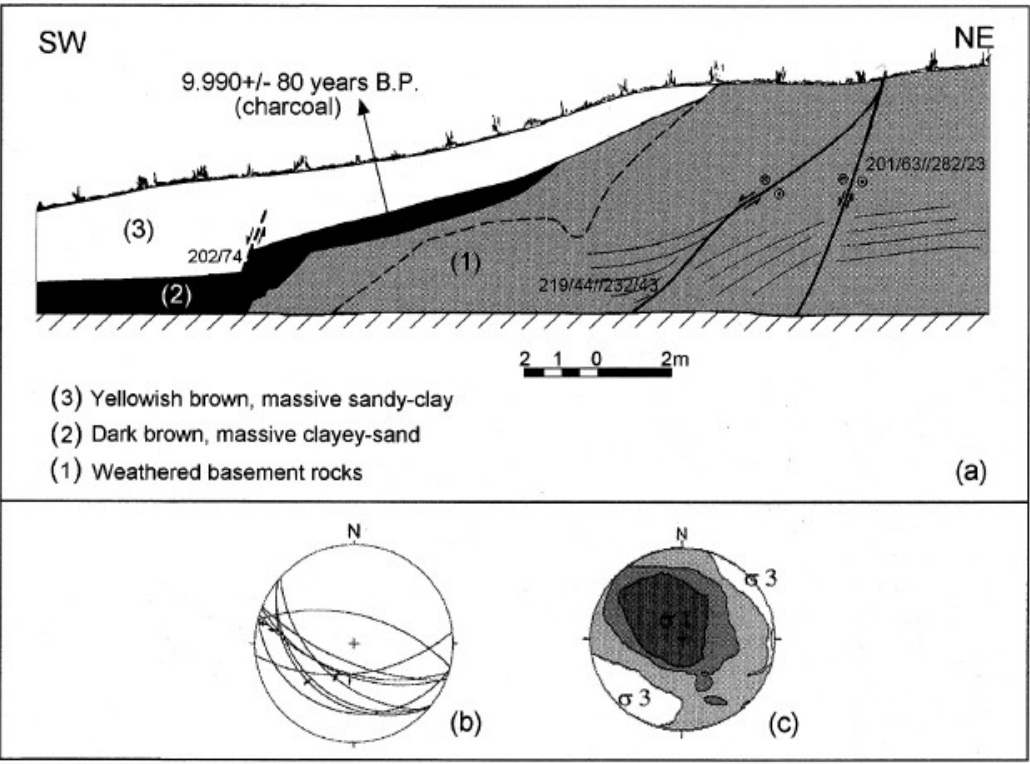

FIGURE 5 - Córrego Grande (B) Section. (a) Stratigraphic reconstruction, (b) stereographic projection of the fault planes measured in this site and (c) the analysis of them using the ANGELIER \& MECHLER (1977) method. Note the displacement of the Holocene organic-rich horizon by a NW-SE normal fault. 
In the present study it is proposed that this faulting process has conditioned the Holocene alluvial fan sedimentation (sin-sedimentary tectonics) suggesting that the early to middle Holocene alluvial sedimentary event was caused by neotectonic mechanisms related to an E-W dextral transcurrent regime.

\section{LACUSTRINE SEDIMENTATION AND NEOTECTONICS}

The stratigraphic investigation carried out at the mouth of the Dom Helvécio Lake provides new insights about the evolution of the Doce River Middle Valley lake system. A seismic stratigraphic profile was obtained documenting the sedimentary pattern at this site (Figure 6a). An 8 meters long drill hole was obtained, crossing the main seismic stratigraphic units (Figure 6b).

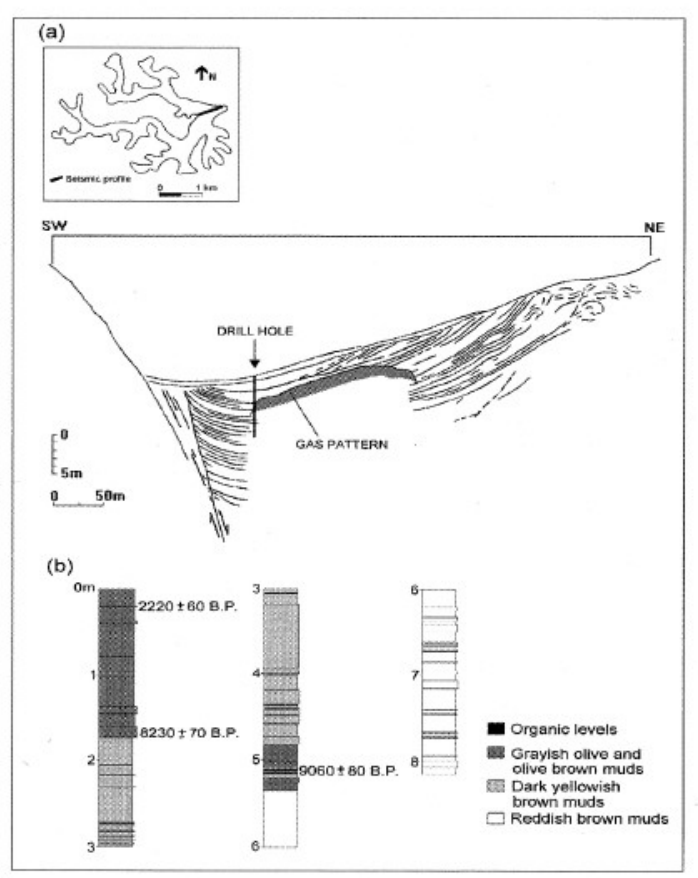

FIGURE 6 - (a) Seismic profile showing the stratigraphic pattern at the mouth of the Dom Helvécio Lake. On the left side, a remarkable structure is seen deforming the seismic reflectors. It was interpreted as a NE-SW normal fault. (b) Stratigraphic reconstruction of the drill hole indicated in (a). First lacustrine conditions are recorded around $9,060 \pm 80{ }^{14} \mathrm{C}$ years BP. Modified from MELLO (1997).

It could be documented that the ancient tributary valley where the Dom Helvécio Lake is now located was filled by alluvial deposits similar to the sediments identified at Fazenda
Conquista (A) Section. This alluvial deposition is characterized by more than 2 meters thick, reddish brown muds that are present on the lower part of the drill hole. Overlying this alluvial materials there is a thin layer of grayish olive, organic muddy sediments, dated at $9,060 \pm 80{ }^{14} \mathrm{C}$ years BP (plants remnants, Beta-97061), which represents a first lacustrine sedimentation. Above this organic level, there are 3 meters thick, brownish muddy sediments, which are interpreted as the record of a fluvial to lacustrine transitional environment. Organic-rich, typically lacustrine sediments are only recorded on the upper part of the drill hole, after 8,230 $70 \pm{ }^{14} \mathrm{C}$ years BP (plant remnants, Beta-97060).

The alluvial to lacustrine sedimentary succession described at the Dom Helvécio Lake mouth is affected by a normal fault plane, probably NE-SW oriented. This plane is recognized on the left side of the seismic profile and can be related to a Holocene NWSE extensional tectonic regime that was regionally identified in the study-area (Figure 3 ). It is a strong evidence for the recent neotectonic control of lake formation.

\section{FINAL REMARKS}

Stratigraphic and structural analyses carried out in the present study suggest that the evolution of the Doce River Middle Valley lake system can be divided in distinctive phases characterized by particular sedimentary and neotectonic mechanisms. Dom Helvécio Lake is considered as a model for this evolution.

A first lacustrine submersion has occurred simultaneously to an intense alluvial sedimentation during early Holocene times. It can be assigned by radiocarbon dates around 9,000 years BP that were obtained from the analyses of alluvial and lacustrine sediments. The early to middle Holocene alluvial deposition resulted in the widespread filling of drainage basins and can be related to an E-W dextral transcurrent tectonic regime. This sedimentary event and this tectonic mechanism are identifiable in other places of Southeastern Brazil as discussed by MELLO et al. (1999). It is supposed that the beginning of lacustrine evolution was caused by concurrent action of tectonic and sedimentary mechanisms.

At the beginning of the lacustrine evolution, the lakes were probably shallow and greatly 
influenced by alluvial processes. It can be inferred from the relatively thick transitional lacustrine to alluvial sedimentation that is recorded just above the organic level dated at 9,000 years BP. Typical lacustrine sediments were only identified after approximately 8,200 years BP.

It is supposed that the final lacustrine evolution of the Doce River Middle Valley lake system was conditioned by the Holocene NESW extensional tectonic regime. The fault plane identified at the mouth of the Dom Helvécio Lake is strong evidence. This tectonic mechanism also explains the Doce River migration and the consequent abandonment of the ancient infilled valley which is observed at the main area of lake concentration, represented by the significant paleochannel trace. As proposed by PFLUG (1969), MEIS (1977) and BARBOSA \& KOHLER (1981), this fluvial migration is directly associated with the lake system origin, but these two related geomorphic aspects are both apparently controlled by a more important tectonic mechanism.

The present study discussed some new evidences of neotectonic controls on the evolution of the Doce River Middle Valley lake system indicating that is important to consider the neotectonic mechanisms beside paleoclimatic inferences to explain the Quaternary landscape evolution of Southeastern Brazil. Discussions about the relationships between neotectonic and paleoclimatic aspects are not attempted here, but represent a future necessary task.

\section{ACKNOWLEDGEMENTS}

This study was supported by FAPESP, CAPES and CEPG-UFRJ. The authors wish to thank Isabela de Oliveira Carmo, Luiz Felipe Rodrigues, Flávia Gonçalves de Castro, Claudio Valdetaro Madeira and Rute Maria Oliveira de Morais for the contributions on several stages of the study, particularly field work. Thanks are due to Dr. Cleverson Guizan Silva (LAGEMAR/UFF) for collaboration on the seismic survey and to Dr. Paulo Eduardo de Oliveira for collaboration on the drillings. The authors are most grateful to the Instituto Estadual de Florestas/IEF-MG, especially the technical staff of the Doce River Forest Park, for support and facilities in the field. Editorial review and comments are also gratefully acknowledged.

\section{REFERENCES}

ALMEIDA, F.F.M; HASUI, Y; NEVES, B.B.B; FUCK, R.A. 1977. Províncias estruturais brasileiras. In: SBG, Simpósio de Geologia do Nordeste, 8, Campina Grande (PB), Atas, 363-391.

ANGELIER, J. \& MECHLER, P. 1977. Sur une méthode graphique de recherche des contraintes principales également utilisable en tectonique et en seimologie: la méthode de dièdres droits. Buletin Societé Géologique France, 7:1309-1318.

BARBOSA, G. V. \& KOHLER, H. C. 1981. O sistema lagunar do Parque Estadual do Rio Doce (MG). Boletim SBG/MG, 2:37-46.

BEHLING, H. 1995. A high resolution Holocene pollen record from Lago do Pires, SE Brazil: vegetation, climate and fire history. Journal of Paleolimnology, 14: 253-268.

DNPM. 1978. Folha Geológica Belo Horizonte (SE-23). Projeto Carta Geológica do Brasil ao Milionésimo. MME/DNPM.

IGA-MG. 1977. Mapa geomorfológico
1:500.000. Folha Belo Horizonte. Secretaria de Estado de Ciência e Tecnologia de Minas Gerais, (Projeto RADAR-MG)

MEIS, M.R.M. 1977. As unidades morfoestratigráficas neoquaternárias do médio vale do Rio Doce. Anais Academia Brasileira de Ciências, 49(3):443-459.

\& MACHADO, M.B. 1978. A morfologia de rampas e terraços no Planalto do Sudeste do Brasil (médio vale do rio Doce). Finisterra, 13(26):199-219.

MEIS, M.R.M. \& MONTEIRO, A.M.F. 1979. Upper Quaternary "rampas": Doce river valley, Southeastern Brazilian plateau. $Z$. Geomorph., 23(2):132-151.

MEIS, M.R.M. \& TUNDISI, J.G. 1986. Geomorphological and limnological processes as a basis for lake typology. The middle Rio Doce lake system. An. Acad. bras. Ciênc., 58(1):103-120.

MELLO, C.L. 1997. Sedimentação e Tectônica Cenozóicas no Médio Vale do Rio Doce 
(MG, Sudeste do Brasil) e suas Implicações na Evolução de um Sistema, de Lagos. Instituto de Geociências, Universidade de São Paulo, São Paulo, Tese de Doutoramento, 275p.

MELLO, C.L; MADEIRA, C.V; MOURA, J.R.S. 1999. Early to middle Holocene environmental instability in SE Brazil (Manso Event) and its influence on development of infilled valleys. In: IGU, GEOVEG99 - Meeting on geomorphic responses to environmental (vegetation) changes - problems and remedial work, Rio de Janeiro, Proceedings, 6p.

NIMER, E. 1989. Climatologia do Brasil. Rio de Janeiro, IBGE, $421 \mathrm{p}$.

PFLUG, R. 1969. Quaternary lakes of Eastern Brazil. Photogrammetria, 24:29-35.

OVERLOOP, E. 1981. Post-glacial to Holocene transition in a peatlayer of Lake Jacare (Rio Doce Basin, Brasil). Bull. Societé Belge de Géologie, 90(2):107-119.

SAADI, A. 1991. Ensaio sobre a Morfotectônica de Minas Gerais. Instituto de Geociências, Universidade Federal de Minas Gerais, Belo Horizonte, Tese de Professor Titular, 285p.

SUGUIO, K; KOHLER, H.C. 1992. Quaternary barred lake systems of the Doce river (Brazil). Anais Academia Brasileira de Ciências, 64(2):183-191.

YBERT, J.P; ALBUQUERQUE, A.L.S; TURCQ, B. 1997. Evolução paleoclimática e paleambiental na região do vale médio do rio Doce (Minas Gerais, Brasil). In: ABEQUA, Congresso da Associação Brasileira de Estudos do Quaternário, 6, Curitiba (PR), Resumos Expandidos, 511-514.

\section{Endereço dos autores:}

Claudio Limeira Mello e Cynthia Maria Soares Metelo - Departamento de Geologia, IGEO/UFRJ. CCMN, Bloco G, Cidade Universitária, Ilha do Fundão, CEP: 21.949-900, Rio de Janeiro (RJ). E-mail: limeira@igeo.ufrj.br 